\title{
COMMENT 221 - Tottering Taliban - leverage to improve the plight of the Afghan people?
}

\author{
By Siegfried O. Wolf \\ 17 November 2021- DOI: 10.48251/SADF.ISSN.2406-5617.C221
}

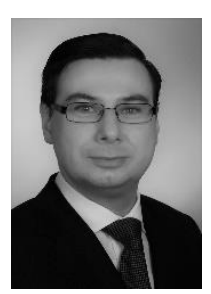

Dr. Siegfried O. Wolf, Director of Research at SADF (Coordinator: Democracy Research Programme); he was educated at the Institute of Political Science (IPW) and South Asia Institute (SAI), both Heidelberg University. Additionally he is member (affiliated researcher) of the SAI as well as a former research fellow at IPW and Centre de Sciences Humaines (New Delhi, India). Dr Wolf works as a consultant to NATO-sponsored periodic strategic independent research and assessment of AfghanistanPakistan issues.

From blaming Washington alone for the dramatic developments in Afghanistan since the US withdrawal, most observers now focus on addressing the plight of the Afghan people and the puzzle of finding an appropriate approach towards the new Taliban government in Kabul. The question over the recognition of the Taliban government seems to dominate international public diplomacy. Lessons from the Afghan imbroglio, the future of counterterrorism and counterinsurgency strategies by both the US and NATO, the role of regional actors constitute additional topics discussed worldwide. There is no doubt that all these considerations are crucial, as immediate humanitarian support to the Afghan people is of utmost importance. However, one of the most significant puzzles appears to be largely side-lined by analysts: how sustainable is the new Islamic Emirate? And would a tottering Taliban regime provide the international community leverage to pressure on commitments as agreed in the 2020 Doha agreement (and reiterated in latest Taliban statements)?

From a political-administrative point of view, it seems that last August the Taliban gained nationwide, effective control in Afghanistan. It is held that their current rule is much more entrenched than during the first Islamic Emirate from 1996 to 2001. From a military perspective, there is - at least until now - the notion that the Taliban are unstoppable.

When observing the war crimes and ongoing atrocities against the Afghan people perpetrated by the Taliban as well as the regime composition - predominantly comprised of religious and militant hardliners -, it becomes clear that the former 
insurgents are not able to transform overnight from a guerrilla movement into a political force capable of running state affairs in a war-torn country. The Taliban leadership lack an 'idea to govern'; nor do their rank and files show any aptitude to take concrete steps to address the rapidly deteriorating living conditions of Afghans or contain the checkless dissolution of state structures. Instead, the new rulers prefer to deal with military organisational tasks or remain busy with internal struggles over the distribution of the most lucrative ministries, government posts, and remits promising the best monetary rewards. The strategy to replace the top echelon of the country's administration, bureaucracy, police, and other institutions from the national to the provincial level has severe negative ramifications. Foremost, it is depriving the remaining state apparatus from much-needed expertise, creating a gap which can't be bridged by unskilled Taliban fighters. The way the Taliban continue to mistreat minorities, violate human rights, and suppress women exposes clearly that the notion of a moderate Taliban 2.0 is an illusion.

Another serious issue of concern is the collapsing economy in Afghanistan. According to the United Nations, the country 'is on the brink of the world's worst humanitarian crisis'. It is estimated 'that some $23 \mathrm{~m}$ of the country's $38 \mathrm{~m}$ people will not have enough food to get through the winter', hardly any access to drinking water, medical care and proper shelter. The repercussions of the pandemic and devastating droughts contributed to the acute food crisis and increased overall poverty. Over $\underline{675,000}$ citizens are internally displaced. The prices for food and other essentials are soaring, while earnings are plummeting. The national currency (Afghani) is deprecating and the Taliban's decision to ban the use of all foreign currency is further complicating economic and trade activities. The central bank's assets were frozen. That international financial institutions suspended the access to funds is speeding up the dysfunction of the banking sector, leaving most Afghans without access to basic financial services. The closing of borders by neighbouring states led to severe disruptions to trade, with far-reaching, negative impacts for the agricultural sector. The interim government cannot pay its bills; most public

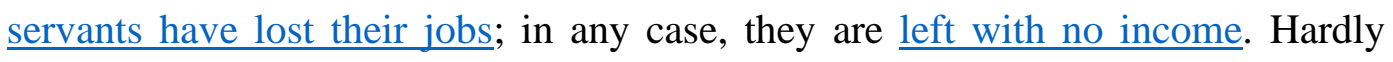
anyone has money in Afghanistan right now, and major as well as smaller businesses are closing. According to the IMF, Afghanistan's economy will shrink by up to $30 \%$ this year. 
Along with economic conditions, the law-and-order situation is also breaking down. Robberies, extortions, kidnapping and killing for ransom are becoming rather the norm. Instead of curtailing the excruciatingly high crime levels, the Taliban contribute to these. Reports of Taliban begging for food are further hints that the leadership in Kabul is not able to pay even its own foot soldiers. This is not only forcing the Taliban to get involved in criminal activities but makes them vulnerable for recruitment activities by their currently biggest rival, the Islamic State-Khorasan Province (IS-K). Here, it's crucial to mention that besides the Taliban's capture of Afghanistan's urban areas, the real military strength of the movement concerns its influence in rural areas (based on guerrilla warfare tactics). Yet, unlike in the country, the Taliban seem to lack the skills and capacities needed to ensure security in cities - apparently increasing the IS-K's leverage, and generally making the security situation evolve "from bad to worse". The increasing number of terror attacks, especially those targeting Taliban fighters, indicates that the IS-K is using the urban power vacuum to advance its positions. It seems that the Taliban's advantages in numerical strength and equipment are losing relevance in its confrontation with the IS-K. Some hold that the IS-K's efforts in portraying and establishing themselves as a 'resistance movement against the Taliban' could be successful, at least in urban Afghanistan.

As the Taliban continue not to deliver services -including security, law and order and fail to tackle humanitarian and economic crises, what is likely to happen? Nazifullah Salarzai, H. E. Ambassador of Afghanistan to the Kingdom of Belgium, EU, and NATO, stressed at a conference organised by the South Asia Democratic Forum that they would 'have to face the anger of the Afghan people'. This view is reflected by expert Waliullah Rahmani, who states that '[...] people have grown frustrated and this situation needs just a small spark to change to unrest'. By all accounts, it does not seem that the Taliban can succeed in consolidating power more broadly. In fact, it appears that their grip over the country is waning. According to a thoughtful analysis by Sarah Chayes, this could provide the US and its allies with 'leverage' over the Taliban and emphasize that ' $[\mathrm{t}]$ hey should not allow the Taliban to turn the Afghan population into hostages, brandishing their suffering to extract financial assistance and international legitimacy with no strings attached.' With the 'European Parliament resolution of 16 September 2021 on the situation in Afghanistan', a first (humble) step by a European institution in the right direction 
was undertaken by recalling ' $[\ldots]$ that for the EU, a critical litmus test of any kind of relationship with the Taliban will be the preservation of the achievements of the last 20 years [point 21] and urges the 'Commission to swiftly launch an investigation pursuant to Article 19(1)(a) of the GSP Regulation with a view to suspending the trade preferences that Afghanistan has under the Everything But Arms scheme' [point 22]. This can be interpreted as a signal to the Taliban that the European Parliament will insist on past promises regarding woman rights and political inclusivity, among other pressing issues. However, it remains to be seen how far the European Commission (EC) and the European External Action Service (EEAS) will perceive the parliamentarian's call and put them into political praxis. To sum up with Chayes' words: 'Just because we've failed to use our leverage in the past doesn't mean we shouldn't start now.' 


\section{References:}

Al Jazeera. (2021, November 2). Taliban bans the use of foreign currency across Afghanistan.

https://www.aljazeera.com/news/2021/11/2/taliban-bans-use-of-foreigncurrency-across-afghanistan

Alavi, L.J. (2021, November 4) Why the Taliban must be held accountable for past atrocities. Blog. The Conversation.

https://theconversation.com/why-the-taliban-must-be-held-accountablefor-past-atrocities-169281

Blue, V.J., Gibbons-Neff, T., \& Goldbaum, C. (2021? November 3). ISIS Poses a Growing Threat to New Taliban Government in Afghanistan. The New York Times.

https://www.nytimes.com/2021/11/03/world/asia/isis-afghanistantaliban.html

Chayes, S. (2021, November 13). The Taliban Is Vulnerable. Here's How to Seize the Moment. Opinion. Politico.

https://www.politico.com/news/magazine/2021/11/13/the-taliban-isweaker-than-we-think-520919

The Economist. (2021, October 30). Afghanistan's economy is collapsing.

https://www.economist.com/asia/2021/10/30/afghanistans-economy-iscollapsing

European Parliament. (2021). Situation in Afghanistan. European Parliament resolution of 16 September 2021 on the situation in Afghanistan. P9_TA(2021)0393, (2021/2877(RSP)).

https://www.europarl.europa.eu/doceo/document/TA-9-20210393_EN.pdf

George, S., Warrick, J., DeYoung, K. (2021, October 23). Pakistan using informal intelligence channels to prop up Taliban fight against ISIS. The Washington Post.

https://www.washingtonpost.com/world/2021/10/23/afghanistan-isispakistan-intelligence/

Hein, S. (2021, November 11). Afghanistan: Can the Taliban avert a food crisis without foreign aid? Deutsche Welle (DW). 
https://www.dw.com/en/afghanistan-can-the-taliban-avert-a-food-crisiswithout-foreign-aid/a-59790464

International Organisation for Migration. (2021, November 1). IOM Afghanistan Situation Report \#11, 21 - 27 October 2021.

https://reliefweb.int/report/afghanistan/iom-afghanistan-situation-report-

\section{1-21-27-october-2021}

Kugelman, M. (2021, November 10). The Politics of Taliban Recognition. South Asian Voices. Washington, D.C.: Stimson Center. https://southasianvoices.org/the-politics-of-taliban-recognition/

Najibullah, L. (2021, November 8). Taliban retitles all military corps in Afghanistan. The Kaama Press News Agency.

https://www.khaama.com/taliban-retitles-all-military-corps-in-afghanistan$\underline{45747 /}$

O’Donnell, L. (2021, October 11). Pakistan's Ambassador to Kabul: 'Engagement Has to Continue' With Taliban Government. Foreign Policy. https://foreignpolicy.com/2021/10/11/taliban-afghanistan-pakistanrelations-peace-security-economy-ambassador-interview/

O’Donnell, L. (2021, October 29). Afghan Crime Wave Adds to Taliban Dystopia. Foreign Policy.

https://foreignpolicy.com/2021/10/29/afghanistan-crime-poverty-talibaneconomic-collapse-humanitarian-crisis/

O’Donnell, L. (2021, November 1). As Afghanistan Nears Collapse, Taliban 'Between a Rock and a Hard Place'. Foreign Policy. https://foreignpolicy.com/2021/11/01/afghanistan-taliban-collapseintelligence-security-resistance-poverty-rahmatullah-nabil/

Radio France Internationale. (2021, November 8). Taliban victory sparks hopes of peace in rural Afghanistan.

https://www.rfi.fr/en/taliban-victory-sparks-hopes-of-peace-in-rural$\underline{\text { afghanistan }}$

Reuters. (2021, October 19). Afghanistan's economic collapse could prompt refugee crisis - IMF. https://www.reuters.com/world/asia-pacific/afghanistans-economiccollapse-could-prompt-refugee-crisis-imf-2021-10-19/ 
Reuters. (2021, November 7). Taliban appoint members as 44 governors, police chiefs around Afghanistan.

https://www.reuters.com/world/asia-pacific/taliban-appoint-members-44governors-police-chiefs-around-afghanistan-2021-11-07/

South Asia Democratic Forum. (2021, November 3). Rethinking Afghanistan. Conference recording. https://www.youtube.com/watch?v=9j-B_qrU-IU

Sirat, H., \& Hakimi, H. (2021, November 8). Afghanistan: People struggle to make ends meet amid economic turmoil. Deutsche Welle (DW). https://www.dw.com/en/afghanistan-people-struggle-to-make-ends-meetamid-economic-turmoil/a-59756824

Tolo News. (2021, October 28). Kidnapping Cases Surge in Afghanistan. https://tolonews.com/afghanistan-175208

United States Department of States (2020, February 29). Agreement for Bringing Peace to Afghanistan between the Islamic Emirate of Afghanistan which is not recognized by the United States as a state and is known as the Taliban and the United States of America. https://www.state.gov/wp-content/uploads/2020/02/Agreement-ForBringing-Peace-to-Afghanistan-02.29.20.pdf 